\title{
An assessment of the value of midfinger smears in multibacillary leprosy patients
}

\author{
LALITHA HARI, D. SURYANARAYANAN, \\ ALEYAMMA THOMAS \& PAULIN JOSEPH \\ Tuberculosis Research Centre (Indian Council of Medical Research), \\ Mayor V. R. Ramanathan Road, Chetput, Chennai-600 031, India
}

\author{
Accepted for publication 21 December 1998
}

\begin{abstract}
Summary In view of the different opinions on fingers as sites for persisting bacilli in multibacillary leprosy patients, it was decided to examine the midfingers for the presence of acid-fast bacilli (AFB) and establish its usefulness. Sixty-nine multibacillary leprosy patients, [lepromatous (LL) and borderline lepromatous (BL)] treated with multidrug therapy for fixed duration ( 2 years) were analysed. The bacillary load in the midfinger sites was lower when compared to that in the 'compulsory' (both earlobes) and 'optional' (four active lesions) sites. The midfinger bacterial index (BI) was higher among LL patients when compared to BL patients $(p<0.001)$. However, the difference in mean $\mathrm{BI}$ in 'optional' and 'compulsory sites' was not significant. The overall fall in BI was gradual and on expected lines for all sites, including midfingers, during treatment and follow-up period. Except in one case, at no time were the smears from midfinger sites positive when all other sites were negative, and their inclusion did not contribute to the early detection of relapse. Furthermore, the collection of blood-free smears from this site is technically difficult and of ten painful for the patient. The inclusion of midfinger smears in this study in patients in South India did not contribute useful information to that which is routinely available from smears of earlobes and other active sites.
\end{abstract}

\section{Introduction}

Untreated lepromatous leprosy is characterized by the presence of a heavy load of bacilli from any area in the skin. Following adequate treatment with multidrug therapy (MDT), the bacterial load declines gradually. It has been reported by Ridley and Jopling ${ }^{1}$ that in longterm treated patients, solid staining bacilli may sometimes be found in the slit skin smear from the dorsum of the finger (though there are no apparent lesions on the fingers) when other sites are bacteriologically negative. It has also been reported that finger smears are early indicators of relapses due to persisting bacilli. ${ }^{3}$ There are other reports in the literature both for and against the superiority of finger smears over routine slit skin smears. ${ }^{2-7}$ 
The aim of the present report was to examine the value of midfinger smears in multibacillary (MB) leprosy patients who were treated with fixed duration MDT (2 years) and followed up for a period of 60 months.

\section{Materials and methods}

MB leprosy patients with bacterial index (BI) of 2.5 or more (on six sites) admitted to a controlled clinical trial of MDT for fixed duration were the subjects.

Slit skin smears for the presence of AFB were taken from six sites, namely, both earlobes as 'compulsory' sites (CS) and four active lesions as 'optional' sites (OS) on admission, at 3 months, 6 months and thereafter every 6 months up to 60 months. ${ }^{5}$

Finger smears ${ }^{2}$ were taken from the dorsum of both midfingers (MF) on admission, at 24 months and thereafter every 6 months up to 60 months. BI grading was done by the RidleyJopling method. Results from CS, OS and midfinger sites were compared at different time periods. Histopathological examination was done to confirm the clinical diagnosis.

\section{Results}

On admission, midfinger smears were taken from 99 patients. Thirty patients were excluded (nine died, 19 failed to attend or were non-cooperative, and two migrated) and the remaining 69 were analysed. Of the 69 patients, 32 (46\%) were histopathologically classified as LL, 35 $(51 \%)$ as $\mathrm{BL}$ and for two patients the classification was not available (clinically classified as BL and LLp).

\section{MIDFINGERS VERSUS COMPULSORY SITES}

On admission, in 36 (52\%) of 69 patients, the mean BI in the CS sites was higher than in the midfingers. Only six (9\%) had a higher mean BI in the midfingers than in the CS (Table 1).

Table 1. Midfingers versus 'compulsory sites' (mean BI) on admission

\begin{tabular}{lccrrr}
\hline & \multicolumn{5}{c}{ 'Compulsory sites' } \\
\cline { 2 - 4 } MF & $2.0-$ & $3.0-$ & $4.0-$ & $5.0-$ & Total \\
\hline 0.0 & 1 & 0 & 2 & 0 & 3 \\
$1 \cdot 0-$ & 0 & 2 & 2 & 0 & 4 \\
$2 \cdot 0-$ & 0 & 1 & 1 & 0 & 2 \\
$3 \cdot 0-$ & 1 & 0 & 10 & 4 & 15 \\
$4 \cdot 0-$ & 0 & 1 & 23 & 13 & 37 \\
$5 \cdot 0-$ & 0 & 2 & 2 & 4 & 8 \\
Total & 2 & 6 & 40 & 21 & 69 \\
& & & & & \\
\hline
\end{tabular}


Table 2. Midfingers versus 'optional sites' (mean BI) on admission

\begin{tabular}{lrrrrr}
\hline & \multicolumn{5}{c}{ 'Optional sites' } \\
\cline { 2 - 4 } MF & $2.0-$ & $3.0-$ & $4.0-$ & $5.0-$ & Total \\
\hline $0 \cdot 0$ & 2 & 0 & 1 & 0 & 3 \\
$1 \cdot 0-$ & 1 & 1 & 2 & 0 & 4 \\
$2 \cdot 0-$ & 0 & 0 & 1 & 1 & 2 \\
$3.0-$ & 1 & 5 & 8 & 1 & 15 \\
$4 \cdot 0-$ & 1 & 6 & 27 & 3 & 37 \\
$5.0-$ & 0 & 0 & 5 & 3 & 8 \\
Total & 5 & 12 & 44 & 8 & 69 \\
& & & & & \\
\hline
\end{tabular}

\section{MIDFINGERS VERSUS OPTIONAL SITES}

While comparing midfinger smears with OS, it was found that $21(30 \%)$ of 69 patients had higher mean BI in the OS and $13(19 \%)$ had higher mean BI in the midfingers (Table 2).

For three patients (all BL cases), the BIs from midfinger smears were negative on admission as well as in the post-treatment period, whereas the BI from the CS and OS were positive up to 24 months.

\section{COMPARISON OF MEAN BI AMONG LL AND BL PATIENTS}

While there was no significant difference in the mean BI in CS and OS between the LL and BL group, the midfinger smear positivity among the BL patients was significantly less than that of LL patients $(p \leq 0 \cdot 001)$ at all the time periods (Table 3$)$.

The mean BI in the midfingers were found to be less than those of the CS and OS in both

Table 3. Comparison of the mean bacterial index (BI) among LL and BL patients

\begin{tabular}{|c|c|c|c|c|c|c|}
\hline & & $\begin{array}{l}0 \text { month } \\
\text { Mean BI }\end{array}$ & $\begin{array}{c}24 \text { months } \\
\text { Mean BI }\end{array}$ & Fall & $\begin{array}{l}60 \text { months } \\
\text { Mean BI }\end{array}$ & Fall \\
\hline \multirow{3}{*}{$\begin{array}{l}\mathrm{LL} \\
(n=32)\end{array}$} & CS & $\begin{array}{l}4 \cdot 64 \\
(3 \cdot 5-5 \cdot 5)\end{array}$ & $\begin{array}{l}3 \cdot 83 \\
(1 \cdot 0-5 \cdot 0)\end{array}$ & $0 \cdot 81$ & $\begin{array}{l}1 \cdot 35^{*} \\
(0 \cdot 0-4 \cdot 0)\end{array}$ & 3.29 \\
\hline & OS & $\begin{array}{l}4 \cdot 39 \\
(2 \cdot 5-5 \cdot 5)\end{array}$ & $\begin{array}{l}3 \cdot 18 \\
(0 \cdot 25-4 \cdot 5)\end{array}$ & 1.21 & $\begin{array}{l}1 \cdot 19 * \\
(0 \cdot 0-3 \cdot 25)\end{array}$ & $3 \cdot 20$ \\
\hline & MF & $\begin{array}{l}4 \cdot 13 \\
(2 \cdot 0-5 \cdot 0)\end{array}$ & $\begin{array}{l}2 \cdot 63 \\
(0 \cdot 0-4 \cdot 0)\end{array}$ & 1.50 & $\begin{array}{l}0.71 * \\
(0 \cdot 0-3 \cdot 0)\end{array}$ & 3.42 \\
\hline \multirow{3}{*}{$\begin{array}{l}\mathrm{BL} \\
(n=35)\end{array}$} & $\mathrm{CS}$ & $\begin{array}{l}4 \cdot 17 \\
(2 \cdot 0-5 \cdot 5)\end{array}$ & $\begin{array}{l}2 \cdot 71 \\
(0 \cdot 0-6 \cdot 0)\end{array}$ & 1.46 & $\begin{array}{l}0 \cdot 60 \\
(0 \cdot 0-3 \cdot 5)\end{array}$ & 3.57 \\
\hline & OS & $\begin{array}{l}3.91 \\
(2 \cdot 0-5.0)\end{array}$ & $\begin{array}{l}2 \cdot 25 \\
(0 \cdot 0-4 \cdot 25)\end{array}$ & 1.66 & $\begin{array}{l}0 \cdot 64 \\
(0 \cdot 0-3 \cdot 5)\end{array}$ & 3.27 \\
\hline & MF & $\begin{array}{l}3 \cdot 17 \\
(0 \cdot 0-5 \cdot 0)\end{array}$ & $\begin{array}{l}1 \cdot 70 * * \\
(0 \cdot 0-4 \cdot 5)\end{array}$ & 1.47 & $\begin{array}{l}0.30 \\
(0 \cdot 0-3 \cdot 5)\end{array}$ & $2 \cdot 87$ \\
\hline
\end{tabular}

Histopathology not done for two patients.

*One patient failed to attend at 60 months.

**MF smear not done for two patients. 
Table 4. Comparison of the bacterial status at 60 months among midfinger, 'compulsory' sites and 'optional' sites

\begin{tabular}{llllllc}
\hline & & \multicolumn{2}{c}{ CS } & & \multicolumn{2}{c}{ OS } \\
\cline { 3 - 4 } \cline { 5 - 7 } MF & $n$ & Pos & Neg & & Pos & Neg \\
\hline Pos & 24 & 17 & 7 & & 22 & 2 \\
Neg & 44 & 22 & 22 & & 22 & 22 \\
Total & $68^{*}$ & 39 & 29 & & 44 & 24 \\
\hline
\end{tabular}

*One patient failed to attend (FTA) at 60 months.

LL and BL groups during all the time points, though the rate of fall in the mean BI was similar in the $\mathrm{LL}$ and $\mathrm{BL}$ groups.

Of the 24 patients who were positive for midfingers, seven were negative for CS and two were negative for the OS at the end of 60 months. Of the 44 patients who were negative for midfingers, 22 were positive for CS and an equal number were positive for OS (Table 4). There was only a slight agreement (kappa $=0 \cdot 18)$ between midfingers with $C S$, while the agreement between midfingers with OS was fair $(\mathrm{kappa}=0 \cdot 35)$.

\section{Discussion}

It has been reported by Ridley et al. ${ }^{1}$ in a study on $30 \mathrm{LL}$ patients that midfinger sites had high bacterial load and contained the greatest number of solid staining bacilli. This was all the more striking as there were no lesions on the fingers. In India, Hiramalini et al., ${ }^{2}$ in a study on $41 \mathrm{LL}$ patients, found that the fingers were the sites with the highest bacillary load and more productive than the earlobes. However, Macrery, ${ }^{6}$ in the Lepra Control Project, Malawi during July 1986 to May 1987, showed that the finger smear was generally not useful and their BI results were different from those previously published. In his study based on 278 smears, in $71.2 \%$ of the smears the BI of the finger site was the lowest.

In our study among 69 patients, the bacillary load was less in the midfingers when compared to the bacillary load in the CS and OS. When LL and BL patients were compared, the midfinger BI value was higher among LL patients. However, the difference in the mean $\mathrm{BI}$ among the LL and BL patients in the compulsory and optional sites was not significant.

In our study, the overall fall in BI was gradual and on expected lines for all the sites, including the midfingers, during treatment as well as the follow-up period. All the patients have been followed up for up to 60 months. We did not find any solid bacilli in the midfingers as reported by earlier authors. We have also not come across any relapse so far. In our earlier study on multibacillary leprosy patients, ${ }^{8}$ there were two relapses at 162 and 177 months after 4-5 years of negativity and in both these patients the BI readings from the midfinger sites were negative in the pre-relapse as well as in the relapse period, although the routine skin smears became positive at the time of relapse (BI 2.75 and 1.33 , respectively).

There are many practical difficulties in taking midfinger smears because as the years pass by, subcutaneous tissues are replaced by fibrous tissues and therefore the skin over the fingers become firm. Further, it is not always possible to pinch sufficient thickness of skin and most 
of the time it becomes difficult to collect blood-free tissue material for smears. Moreover, the procedure is painful for the patient because of the high sensitivity of the area. As the BI value is lower in the midfingers than in the other sites, and also since they are not early indicators of relapse, we suggest that it is better to restrict the taking of multiple smears, when indicated, from the earlobes and other active 'optional' sites.

\section{Acknowledgment}

The authors gratefully acknowledge Mr M. Nagarajan, Senior Technical Officer, for his critical comments and valuable suggestions, Dr V. D. Ramanathan, Assistant Director for reporting on the biopsies and Mrs S. Sivagamasundari, Laboratory Technician for technical support in the laboratory. We are also grateful to the Medical Social Workers and Nursing staff for valuable assistance in the clinical work.

\section{References}

1 Ridley MJ, Jopling WH, Ridley DS. Acid-fast bacilli in the fingers of long-treated lepromatous patients. Lepr Rev, 1976; 47: 93-96.

${ }^{2}$ Hiramalini S, Joseph NA, Chacko CJG. Concentration and persistence of bacilli in the fingers and toes of patients with lepromatous leprosy. Lepr Rev, 1978; 49: 223-229.

3 Jopling WH, Rees RJW, Ridley DS, Ridley MJ, Samuel NM. The fingers as sites of leprosy bacilli in pre-relapse patients. Lepr Rev, 1979; 50: 289-292.

4 Jopling WH. A report on two follow-up investigations of the Malta Project. Lepr Rev, 1986; 57: 47-52.

5 Ahmed HA, Belehu A, Stoner G., Touw J., Atlaw T. Selection of sites for slit-smears. Lepr Rev, 1979; 50: 283-287.

6 Macrery RT. Slit-skin smears from the fingers in leprosy. Lepr Rev, 1988; 59: 360-361.

7 Warndorff-Van Diepen T. Smear site selection with particular reference to the fingers. A study of 244 long treated lepromatous patients. Int J Lepr, 1982; 50: 39-42.

8 Thomas A, Hari L, Nagara jan M, Prabhakar R. Relapse during long term follow-up with drug susceptible $M$. leprae among multibacillary leprosy patients treated with multidrug therapy regimens; case report. Int J Lepr, 1995; 63: 391-394. 